TITLE:

\title{
Site-specific DNA oxidation by a dinuclear copper complex containing a photoisomerizable azobenzene ligand
}

\section{AUTHOR(S):}

Ito, Takeo; Akamatsu, Kanako; Takeuchi, Kouhei; Satani, Manami; Tanabe, Kazuhito; Nishimoto, Seiichi

\section{CITATION:}

Ito, Takeo ... [et al]. Site-specific DNA oxidation by a dinuclear copper complex containing a photoisomerizable azobenzene ligand. Inorganica Chimica Acta 2013, 408: 230-234

\section{ISSUE DATE:}

2013-11

URL:

http://hdl.handle.net/2433/179479

\section{RIGHT:}

(c) 2013 Elsevier B.V.; この論文は出版社版でありません。引用の際には 出版社版をご確認ご利用ください。; This is not the published version. Please cite only the published version. 


\title{
Site-Specific DNA oxidation by a Dinuclear Copper Complex
}

\author{
Containing a Photoisomerizable Azobenzene Ligand
}

\section{Takeo Ito*, Kanako Akamatsu, Kouhei Takeuchi, Manami Satani, Kazuhito Tanabe and Sei-ichi Nishimoto}

Department of Energy and Hydrocarbon Chemistry, Graduate School of Engineering, Kyoto University, Kyoto 615-8510, Japan.

*Corresponding author. Tel.: +81-75383 7054; Fax: +81753832504

E-mail address: takeoit@scl.kyoto-u.ac.jp

\begin{abstract}
A dinuclear copper complex possessing an azobenzene backbone $\left(\mathrm{Cu}_{2}^{\mathrm{II}} \mathbf{1}\right)$ was synthesized and its affinity towards DNA was investigated and found to be dependent on the trans-cis isomeric forms. Upon exposure to UV light at $365 \mathrm{~nm}$ the trans form of the complex $\left(\mathrm{Cu}_{2}{ }_{2}\right.$ trans-1) underwent photoisomerization into the cis-isomer $\left(\mathrm{Cu}_{2}{ }_{2}\right.$ cis-1), which reverted to the original trans-form on exposure to visible light at $420 \mathrm{~nm}$. Both the trans and cis isomers exhibited moderate DNA cleavage activity toward plasmid duplex DNA in the presence of a reducing agent 3-mercaptopropionic acid (MPA) suggesting that the $\mathrm{Cu}^{\mathrm{I}}$ species could activate molecular oxygen to form a
\end{abstract}


reactive oxygen species in situ. Interestingly, the isomeric copper complexes showed different site-specificities in the oxidation of an oligodeoxynucleotide having single-strand-double-helix junctions in the sequence. The trans isomer $\mathrm{Cu}_{2}^{\mathrm{I}}$ trans-1 induced oxidation at the consecutive deoxyguanosine site (GG) near the junction; on the other hand, such site-specificity was not observed in the case of $\mathrm{Cu}_{2}^{\mathrm{I}}$ cis-1.

Keywords: Multinuclear copper complex; Photoisomerization; $\mathrm{H}_{2} \mathrm{O}_{2}$; DNA oxidation; Azobenzene 


\section{Introduction}

Transition metal complexes capable of interacting with DNA have been developed as artificial nucleases for determining the structure and dynamics of DNA and its assembly with proteins [1-5]. Some multinuclear copper complexes show high nucleobase affinity and structure-dependent DNA cleavage activity via the formation of a reactive oxygen species. Researchers have previously demonstrated that multinuclear copper (II) complexes promote efficient oxidative DNA cleavage especially at the junction of single- and double-stranded DNA in the presence of reducing agents (e.g., 3-mercaptopropionic acid [MPA]) and dioxygen [6-11]. The present study was inspired by interesting findings of earlier studies, which showed that the ligand structure and the distance between the copper centers of the complexes could alter the mode of dioxygen activation and site-specificity of the DNA cleavage [11,12], leading to the design and synthesis of a dinuclear copper complex.

The conformation of the ligand and the distance between two copper centers were reversibly altered by photo-irradiation, and its DNA oxidation activity was evaluated as a new type of metallonuclease. Recently, Hirota and co-workers have developed structurally similar dinuclear metal complexes and investigated hydrolysis of DNA duplex by the isomeric forms of the complexes, and have found that only cis-forms induce hydrolysis of DNA [13,14]. They also attempted redox cleavage of DNA by employing dinuclear copper-dipeptides complexes containing azobenzene structures, but failed to observe conformation dependent activity toward duplex DNA [14]. We thus focused our attention on the copper-catalyzed activation of molecular oxygens by our developed dinuclear copper complexes and studied structure-dependent DNA oxidation as described below. 


\section{Experimental}

\subsection{General methods}

Oligodeoxynucleotides ODN 1 and 2 were purchased from Life Technologies. NMR spectra were recorded on a JEOL EX 400 spectrometer and chemical shifts were expressed in ppm relative to the residual signals of the solvents. Fast atom bombardment (FAB) mass spectrometry was performed on a JEOL JMS-SX 102A mass spectrometer using nitrobenzyl alcohol as a matrix. UV-visible spectra were obtained using a JASCO V-530 UV-Vis spectrophotometer. Monochromatic light of 365 or $420 \mathrm{~nm}$ was obtained from a LAX-101 (100 W) light source (Asahi Spectra) with appropriate filters.

\subsection{Synthesis of Azobenzene ligand 1}

N,N-Bis[2-(2-pyridyl)ethyl]-2-(4-nitrophenyl)ethylamine $(2)^{[15]}$.

To 2-(4-nitrophenyl)ethylamine hydrochloride (Tokyo Chemical Industry, 1.12g, $5.54 \mathrm{mmol}$ ) in $10 \mathrm{ml}$ of $\mathrm{H}_{2} \mathrm{O}$ was added sodium hydroxide $(5 \mathrm{M}$ ) dropwise until $\mathrm{pH}$ became $\sim 9$. The resulting mixture was extracted with chloroform. The organic layer was washed with brine, dried over magnesium sulfate, filtered, and then evaporated. Residual brown solid was dissolved in $5 \mathrm{ml}$ of anhydrous methanol, and stirred in an atmosphere of nitrogen at $80{ }^{\circ} \mathrm{C}$. After the addition of acetic acid $(1.00 \mathrm{ml}, 18.80 \mathrm{mmol})$ and 2-vinylpyridine $(1.00 \mathrm{ml}, 11.28$ mmol), the mixture was refluxed for $8 \mathrm{~h}$ under $\mathrm{N}_{2}$ atmosphere. The resulting mixture was then poured into water and extracted with $\mathrm{Et}_{2} \mathrm{O}$. Organic layer was washed with brine, dried over magnesium sulfate, filtered, and then dried under reduced pressure. Silica gel chromatography (10:1 chloroform/methanol) gave $\mathbf{2}(1.28 \mathrm{~g}, 50.8 \%)$ as a dark brown oil: ${ }^{1} \mathrm{H} \mathrm{NMR}\left(\mathrm{CDCl}_{3}, 400 \mathrm{MHz}\right) \delta(\mathrm{ppm}) 8.50(\mathrm{~d}, \mathrm{~J}=3.9 \mathrm{~Hz}, 2 \mathrm{H}), 8.02(\mathrm{~d}, \mathrm{~J}=8.8 \mathrm{~Hz}, 2 \mathrm{H}), 7.50(\mathrm{~m}$, 2H), $7.14(\mathrm{~d}, \mathrm{~J}=8.8 \mathrm{~Hz}, 2 \mathrm{H}), 7.08(\mathrm{t}, \mathrm{J}=11.5 \mathrm{~Hz}, 2 \mathrm{H}), 6.96(\mathrm{~d}, \mathrm{~J}=7.8 \mathrm{~Hz}, 2 \mathrm{H}), 2.97(\mathrm{~m}, 6 \mathrm{H}), 2.78(\mathrm{~m}, 6 \mathrm{H}) ;{ }^{13} \mathrm{C}$ 
NMR $\left(\mathrm{CDCl}_{3}, 100 \mathrm{MHz}\right) \delta(\mathrm{ppm}) 148.7,148.2,146.0,136.1,129.3,123.3,123.0,121.0,54.6,53.2,35.1,33.0$;

HRMS calcd. for $\mathrm{C}_{22} \mathrm{H}_{25} \mathrm{O}_{2} \mathrm{~N}_{4}\left[(\mathrm{M}+\mathrm{H})^{+}\right]$377.1978, found 377.1985.

\section{Ligand trans-1}

A suspension of $\mathrm{LiAlH}_{4}(1.00 \mathrm{~g})$ in $30 \mathrm{ml}$ of anhydrous $\mathrm{Et}_{2} \mathrm{O}$ was vigorously stirred in an atmosphere of argon at $-78{ }^{\circ} \mathrm{C}$. To this suspension was added $\mathbf{2}$ in $30 \mathrm{ml}$ of anhydrous $\mathrm{Et}_{2} \mathrm{O}$ dropwise. The mixture was allowed to warm to room temperature and then further stirred for $3 \mathrm{~h}$. The reaction was quenched slowly and successively with ethyl acetate, methanol, and $\mathrm{H}_{2} \mathrm{O}$ with vigorously stirring. The mixture was extracted with $\mathrm{Et}_{2} \mathrm{O}$. Organic layer was washed with brine, dried over magnesium sulfate, filtered, and then concentrated under reduced pressure. The crude product was purified by silica gel chromatography (10:1 chloroform/methanol) to give trans-1 $(1.08 \mathrm{~g}, 92.1 \%)$ as an orange oil: ${ }^{1} \mathrm{H} \mathrm{NMR}\left(\mathrm{CDCl}_{3}, 400 \mathrm{MHz}\right) \delta(\mathrm{ppm}) 8.45(\mathrm{~d}, \mathrm{~J}=3.9 \mathrm{~Hz}, 4 \mathrm{H}), 7.94(\mathrm{~d}, \mathrm{~J}=8.5$ Hz, 4H), $7.45(\mathrm{~m}, 4 \mathrm{H}), 7.09(\mathrm{~d}, \mathrm{~J}=8.6 \mathrm{~Hz}, 4 \mathrm{H}), 7.03(\mathrm{t}, \mathrm{J}=10.9 \mathrm{~Hz}, 4 \mathrm{H}), 6.91(\mathrm{~d}, \mathrm{~J}=7.6 \mathrm{~Hz}, 4 \mathrm{H}), 2.92(\mathrm{~m}, 12 \mathrm{H})$, $2.73(\mathrm{~m}, 12 \mathrm{H}) ;{ }^{13} \mathrm{C} \mathrm{NMR}\left(\mathrm{CDCl}_{3}, 100 \mathrm{MHz}\right) \delta(\mathrm{ppm}) 149.2,148.2,144.0,138.1,132.3,126.3,125.0,119.0,55.4$, 54.3, 34.1, 32.0; HRMS calcd. for $\mathrm{C}_{44} \mathrm{H}_{49} \mathrm{~N}_{8}\left[(\mathrm{M}+\mathrm{H})^{+}\right]$689.4081, found 689.4091.

Preparation of $\left[\mathrm{Cu}_{2}{ }_{2}\right.$ trans- $\left.\mathrm{I}\left(\mathrm{ClO}_{4}\right)_{4} \cdot \mathrm{H}_{2} \mathrm{O}\right]$

Copper (II) perchlorate hexahydrate $(0.23 \mathrm{~g}, 0.36 \mathrm{mmol})$ was dissolved in $1 \mathrm{ml}$ of THF and stirred at room temperature. To this solution was added trans $-\mathbf{1}(0.12 \mathrm{~g}, 0.18 \mathrm{mmol})$ in $1 \mathrm{ml}$ of $\mathrm{MeOH}$ dropwise. Obtained solid was further recrystallized from methanol to give the desired product as green solid $(60 \mathrm{mg}, 0.05 \mathrm{mmol}$, 28\%): Anal. Calc. for $\mathrm{C}_{44} \mathrm{H}_{50} \mathrm{C}_{14} \mathrm{Cu}_{2} \mathrm{~N}_{8} \mathrm{O}_{17}$ : C, 42.90; H, 4.09; N, 9.10. Found: C, 42.91; H, 3.97; N, 9.14\%. HRMS calcd. for $\mathrm{C}_{44} \mathrm{H}_{49} \mathrm{~N}_{8} \mathrm{Cu}_{2}\left[(\mathrm{M}+\mathrm{H})^{+}\right]$815.2667, found 815.2665.

\subsection{Oxidative Cleavage of Oligodeoxynucleotides}


Oligodeoxynucleotide ODN 1 or 2 (50 pmol) was radiolabeled with $\left[\gamma_{-}{ }^{32} \mathrm{P}\right]$-ATP (Perkin Elmer, 370

$\mathrm{MBq} / \mathrm{ml}$ ) and T4 Polynucleotide Kinase (Nippon Gene). ODN 1 or $2(1 \mu \mathrm{M})$ containing appropriate amount of the

${ }^{32} \mathrm{P}-$ Labeled ODN was annealed in cacodylate buffer (10 mM sodium cacodylate, $\left.100 \mathrm{mM} \mathrm{NaCl}, \mathrm{pH} 7.0\right)$ by

heating to $90^{\circ} \mathrm{C}$, followed by slow cooling to room temperature. Cis-form complex $\left(\mathrm{Cu}_{2}{ }_{2} \mathrm{cis}-\mathbf{1}\right)$ rich solution was prepared by photo-illumination $(365 \mathrm{~nm})$ to the stock aqueous solution of $\mathrm{Cu}_{2}{ }_{2}$ trans- $\mathbf{1}$ until the absorption spectra indicate the photo-stationary states. The above prepared ODN solution was incubated with various concentrations of copper complex (cis or trans form) and 3-mercaptopropionic acid (MPA, $1 \mathrm{mM}$ ) (total $20 \mu \mathrm{l}$ ) at $37^{\circ} \mathrm{C}$. Reaction was quenched by adding diethyl dithiocarbamic acid (10 $\mathrm{mM})$ [6-11]. DNA products were precipitated by adding $10 \mu \mathrm{L}$ of herring sperm DNA ( $1 \mathrm{mg} / \mathrm{ml}), 5 \mu \mathrm{L}$ of $3 \mathrm{M}$ sodium acetate (pH 5.2) and $400 \mu \mathrm{L}$ of cold ethanol,

followed by chilling at $-20^{\circ} \mathrm{C}$. The precipitated DNA was dissolved in $10 \mathrm{vol} \%$ piperidine, heated at $90{ }^{\circ} \mathrm{C}$ for 20 min, and then dried under reduced pressure. The dried DNA pellets were resuspended in loading buffer ( $8 \mathrm{M}$ urea, $40 \%$ sucrose, $0.025 \%$ xylene cyanol, $0.025 \%$ bromophenol blue). The samples $\left(1 \mu \mathrm{l},(10-40) \times 10^{3} \mathrm{cpm}\right)$ were loaded onto a 20\% polyacrylamide (acrylamide-bisacrylamide 19:1) gel containing $7 \mathrm{M}$ urea, electrophoresed at $70 \mathrm{~W}$, transferred to a cassette, and stored at $-80^{\circ} \mathrm{C}$ with Fuji X-ray films (RX-U). Cleavage of the labelled strand was quantified by autoradiography using the ATTO Densitograph Software (version 3.0). 


\subsection{Plasmid DNA Cleavage}

Duplex DNA cleavage by copper complexes was performed by using supercoiled circular pUC19 Form I DNA (Toyobo). pUC19 (40.0 $\mu \mathrm{M} / \mathrm{bp})$ in Tris-HCl-NaCl buffer (100 mM, pH7.4) was incubated in the presence of 3-mercaptopropionic acid (1 mM) and 0-50 $\mu \mathrm{M}$ of the complex (total volume $10 \mu \mathrm{L}$ ), then the products were quantified by agarose gel electrophoresis $(0.8 \%$ agarose gel, ethidium bromide stain). Single strand DNA cleavage was observed as the formation of relaxed circular DNA (Form II) band. For the quenching assay, $\mathrm{NaN}_{3}(4 \mathrm{mM})$, dimethylsulfoxide (4 $\mathrm{mM}), D$-mannitol (4 mM), $t$-butyl alcohol (4 mM), superoxide dismutase (10 or $20 \mathrm{U})$, and catalase (10 or $20 \mathrm{U}$ ) were used as quenchers (concentrations in parentheses indicate final concentrations). The gels were visualized on a UV transilluminator $\left(\lambda_{\mathrm{ex}}=312 \mathrm{~nm}\right.$, ETX-35.M, Vilber-Lourmat).

\subsection{DNA-Binding Assay}

UV-visible absorption spectra of the copper complex $(50 \mu \mathrm{M})$ in Tris-HCl-NaCl buffer $(5$ $\mathrm{mM}, \mathrm{pH}$ 7.4) were measured under various concentrations of poly dG/poly dC (SIGMA-Aldrich).

The intrinsic binding constants $K_{\mathrm{b}}$ between the complexes and DNA were calculated by the absorption spectral titration data $(\lambda=420 \mathrm{~nm})$ using equation 1.

\section{Results and discussion}

\subsection{Synthesis}


An azobenzene structure was chosen for regulating the conformation of the dinuclear copper ligand (trans-1) in a reversible manner following illumination with UV light (Fig. 1). A dinuclear $\mathrm{Zn}{ }^{\mathrm{II}}$ complex possessing a similar ligand structure has been recently reported, in which the distance between two benzylic carbons of azobenzene moiety was determined to be $\sim 12 \AA$ [13]. The ligand trans-1 was synthesized from 2-(4-nitrophenyl)ethylamine and 2-vinylpyridine in 2 steps (yield 47\%, Scheme 1). Photoinduced isomerization of trans-1 into the cis-form (cis-1) in methanol could be monitored by ${ }^{1}$ H-NMR (Supplementary data, Fig. S1).

Subsequently, trans-1 in methanol was treated with $\mathrm{Cu}^{\mathrm{II}}\left(\mathrm{ClO}_{4}\right)_{2} \bullet 6 \mathrm{H}_{2} \mathrm{O}$ to afford the dinuclear complex $\mathrm{Cu}_{2}{ }_{2}$ trans-1. The copper complex $\mathrm{Cu}_{2}{ }_{2}$ trans-1 underwent trans-cis isomerization upon UV irradiation at $365 \mathrm{~nm}$ and reached the trans-cis photostationary state within $5 \mathrm{~min}$ as observed from the change in absorption spectra (Fig. 2). Further exposure of the $\mathrm{Cu}_{2}{ }_{2}$ cis-1-rich solution to visible light at $420 \mathrm{~nm}$ induced cis-trans isomerization to yield the trans isomer.

(Fig.1)

(Scheme 1)

(Fig. 2)

\subsection{DNA cleavage activity}

The DNA cleavage activity of the complex was investigated and its sequence specificity 
was determined by designing and synthesizing oligodeoxynucleotides (ODNs 1 and 2) that form single-strand-double helix junctions and hairpin structures (Fig. 3A). Sequential deoxyguanosine (GG) sites have been inserted in the middle of the helices (ODNs 1 and 2) and at the junctions (ODN 2) to investigate potential interaction between GG-sites and copper complexes. Non-irradiated $\mathrm{Cu}_{2}{ }_{2}$ trans-1 complex or its isomer that is formed after exposure to UV (Cu ${ }_{2}$ cis-1-rich) $(100 \mu \mathrm{M}$ each $)$ was incubated with $5^{\prime}-{ }^{32} \mathrm{P}$-labeled ODN 1 or ODN $2(1 \mu \mathrm{M})$ at $37^{\circ} \mathrm{C}$ in the presence of MPA $(1 \mathrm{mM})$, which was used as an in situ reducing agent for $\mathrm{Cu}^{\mathrm{II}}$. Then, the samples were treated with hot piperidine to obtain DNA fragments that were digested at oxidatively damaged sites. In the case of ODN 1, non-site-selective weak cleavage bands were detected using polyacrylamide gel electrophoresis (Supplementary data, Fig. S2); on the other hand, in case of ODN 2, which possessed GG sites at the helix-coil junctions, site-specific DNA oxidation was observed especially at the $\mathrm{G}_{14} \mathrm{G}_{15}$ site near the junction (Fig. 3B[a]). Such site-specific oxidation of DNA bases at the helix-coil junction by multi-nuclear copper complexes have been previously reported [6-11]. This specificity disappeared on employing $\mathrm{Cu}_{2}{ }_{2}$ cis-1 rich fraction for the reaction (Fig. 3B[b]), demonstrating the regulation of site-specificities by photoinduced trans-cis isomerization of the complex. Interestingly, strand cleavage was also observed at nucleobases adjacent to the GG sites $\left(\mathrm{C}_{3}\right.$ and $\left.\mathrm{T}_{8}\right)$. Similar specificities have been previously observed for the trinuclear copper complex, which on incubation with oligodeoxynucleotides possessing helix-coil junctions showed site-specific DNA oxidation at 
nucleobases near the GG sites, possibly due to interaction between the copper complex and the GG near the DNA junction [9]. It is thus likely that photoinduced isomerization of the ligand $\mathbf{1}$ affects the accessibility of the complexes toward DNA.

(Fig. 3)

Both isomeric copper complexes showed similar weak strand-cleavage activity towards the double-helix moiety. Supercoiled circular plasmid DNA pUC19 (40 $\mu \mathrm{M} / \mathrm{bp})$ was incubated with either trans or cis complex $(10-50 \mu \mathrm{M})$ at $37^{\circ} \mathrm{C}$ for $30 \mathrm{~min}$, and the products were analyzed using agarose gel electrophoresis. As shown in Fig. 4, nicked circular DNA (Form II) was generated on completion of the reaction in a concentration dependent manner; however, similar DNA-cleavage activity was observed between the isomers.

\subsection{DNA binding ability}

The UV-visible spectra were used to determine the binding affinity of the complexes with poly dG/poly dC duplex DNA. The electronic absorption spectra of both the complexes with varying concentrations of DNA have been displayed in Fig. 5. The results of titration showed relatively low hypochromic change at around $430 \mathrm{~nm}$ and the binding constants $K_{\mathrm{b}}$ of $(4.7 \pm 0.6) \times 10^{6} \mathrm{M}^{-1}$ for $\mathrm{Cu}_{2}{ }_{2}$ trans- $\mathbf{1}$ complex and $(3.6 \pm 0.8) \times 10^{6} \mathrm{M}^{-1}$ for $\mathrm{Cu}_{2}{ }_{2}$ cis-1 were determined from the plot of $[\mathrm{DNA}] /\left(\varepsilon_{\mathrm{a}}-\mathcal{E}_{\mathrm{f}}\right)$ vs. [DNA] using equation $1[16]$,

$$
[\mathrm{DNA}] /\left(\varepsilon_{\mathrm{a}}-\varepsilon_{\mathrm{f}}\right)=[\mathrm{DNA}] /\left(\varepsilon_{\mathrm{b}}-\varepsilon_{\mathrm{f}}\right)+1 / K_{\mathrm{b}}\left(\varepsilon_{\mathrm{b}}-\varepsilon_{\mathrm{f}}\right)
$$


where $\varepsilon_{\mathrm{a}}, \varepsilon_{\mathrm{f}}$ and $\varepsilon_{\mathrm{b}}$ correspond to $A_{\mathrm{obsd}} /[$ Copper complex], the extinction coefficient for the free copper complex and the extinction coefficient for the copper complex in the fully bound form, respectively. The calculated $K_{\mathrm{b}}$ values indicate that the DNA-binding affinities of the complexes are similar and small. These results are consistent with the low DNA-cleavage activity of the complexes towards the double-helix moiety of ODN 1 and ODN 2 as discussed earlier. Thus, it is plausible that the site-specific DNA oxidation could be attributed to the relatively higher accessibility of the trans isomer to the helix-coil junction than the cis isomer.

(Fig. 4)

(Fig. 5)

\subsection{DNA cleavage mechanism}

Previous attempts aimed at regulating DNA cleavage activity by using of dinuclear metal complexes containing an azobenzene have successfully demonstrated that strand scission of DNA depended on the ligand structure and proceeded most likely via the hydrolysis of the phosphodiester bonds of DNA $[13,14]$. On the other hand, our developed complex can be activated only in the presence of a reducing agent like MPA (see Fig. 6, lanes 3 and 4), which implies that $\mathrm{Cu}^{\mathrm{I}}$ complexes generated in situ activate molecular dioxygen to form reactive oxygen species (ROS). DNA cleavage experiments were also conducted in the presence of various ROS scavengers, such as sodium azide ( $\mathrm{NaN}_{3}$ as ${ }^{1} \mathrm{O}_{2}$ quencher), dimethylsulfoxide (DMSO, OH radical scavenger), $D$-mannitol (MAN, OH 
radical scavenger), tert-butyl alcohol (BU, OH radical scavenger), superoxide dismutase ( $\mathrm{SOD}, \mathrm{O}_{2}$ radical anion quencher), and catalase (CAT, $\mathrm{H}_{2} \mathrm{O}_{2}$ quencher). As is evident in Fig. 6, none of the scavengers $\mathrm{NaN}_{3}$, DMSO, BU, MAN, or SOD inhibited strand scission of pUC19 DNA, and only high concentrations of CAT quenched the reaction. The activation mechanism of dioxygen that leads to DNA cleavage is unclear at present, although $\mathrm{H}_{2} \mathrm{O}_{2}$ formation from mononuclear or multinuclear copper complexes have been previously reported $[1,12,17,18]$. Possibly, the $\mathrm{H}_{2} \mathrm{O}_{2}$ thus formed gets further activated by $\mathrm{Cu}^{\mathrm{I}}$ and induces DNA cleavage; however, co-operative $\mathrm{H}_{2} \mathrm{O}_{2}$ activation by the two copper centers of our dinuclear copper complex is not involved in the reaction process, as both the cis and trans isomers showed similar reactivity towards double-stranded DNA.

(Fig. 6)

Thus, we have demonstrated that two isomeric forms of our dinuclear copper complex with azobenzene ligand structures exhibit different site-specificities in the oxidative cleavage of DNA containing single-strand-double-helix junction, which can be regulated by photo-irradiation.

Our developed copper complex could be useful as a metallonuclease, the target specificity of which can be modulated by redesigning ligand structures of the isomeric azobenzene.

\section{Acknowledgment}

This work was supported by a research grant from the Daiwa Securities Health Foundation.

\section{Appendix A. Supplementary material}


Supplementary data associated with this article can be found, in the online version, at **

\section{References}

[1] C. J. Burrows, J. G. Muller, Chem. Rev. 98 (1998) 1109-1151.

[2] T. A. van den Berg, B. L. Feringa, G. Roelfes, Chem. Commun. (2007) 180-182.

[3] Q. Jiang, N. Xiao, P. Shi, Y. Zhu, Z. Guo, Coord. Chem. Rev. 251 (2007) 1951-1972.

[4] C. Liu, L. Wang, Dalton Trans. (2009) 227-239.

[5] K. L. Haas, K. J. Franz, Chem. Rev. 109 (2009) 4921-4960.

[6] K. J. Humphreys, A. E. Johnson, K.D. Karlin, S. E. Rokita, J. Biol. Inorg. Chem. 7 (2002) $835-842$.

[7] K. J. Humphreys, K. D. Karlin, S. E. Rokita, J. Am. Chem. Soc. 124 (2002) 6009-6019

[8] L. Li, K. D. Karlin, S. E. Rokita, J. Am. Chem. Soc. 127 (2005) 520-521.

[9] T. Ito, S. Thyagarajan, K. D. Karlin, S. E. Rokita, Chem. Commun. (2005) 4812-4814.

[10] L. Li, N. N. Murthy, J. Telser, L. N. Zakharov, G. P. A. Yap, A. L. Rheingold, K. D. Karlin, S. E. Rokita, Inorg. Chem. 45 (2006) 7144-7159.

[11] S. Thyagarajan, N. N. Murthy, A. A. Narducci Sarjeant, K. D. Karlin, S. E. Rokita, J. Am.

Chem. Soc. 128 (2006) 7003-7008.

[12] Q. Zhu, Y. Lian, S. Thyagarajan, S. E. Rokita, K. D. Karlin, N. V. Blough, J. Am. Chem. Soc. 130 (2008) 6304-6305. 
[13] A. Panja, T. Matsuo, S. Nagao, S. Hirota, Inorg. Chem. 50 (2011) 11437-11445.

[14] H. Prakash, A. Shodai, H. Yasui, H. Sakurai, S. Hirota, Inorg. Chem. 47 (2008) $5045-5047$.

[15] T. Osako, Y. Tachi, M. Doe, M. Shiro, K. Ohkubo, S. Fukuzumi, S. Itoh, Chem. Eur. J. 10 (2004) 237-246.

[16] A. Wolfe, G. H. Shimer, T. Meehan, Biochemistry 26 (1987) 6392-6396.

[17] S. T. Frey, H. H. J. Sun, N. N. Murthy, K. D. Karlin, Inorg. Chim. Acta 242 (1996) $329-338$.

[18] M. González-Álvarez, G. Alzuet, J. Borrás, M. Pitié, B. Meunier, J. Biol. Inorg. Chem. 8 (2003) 644-652. 


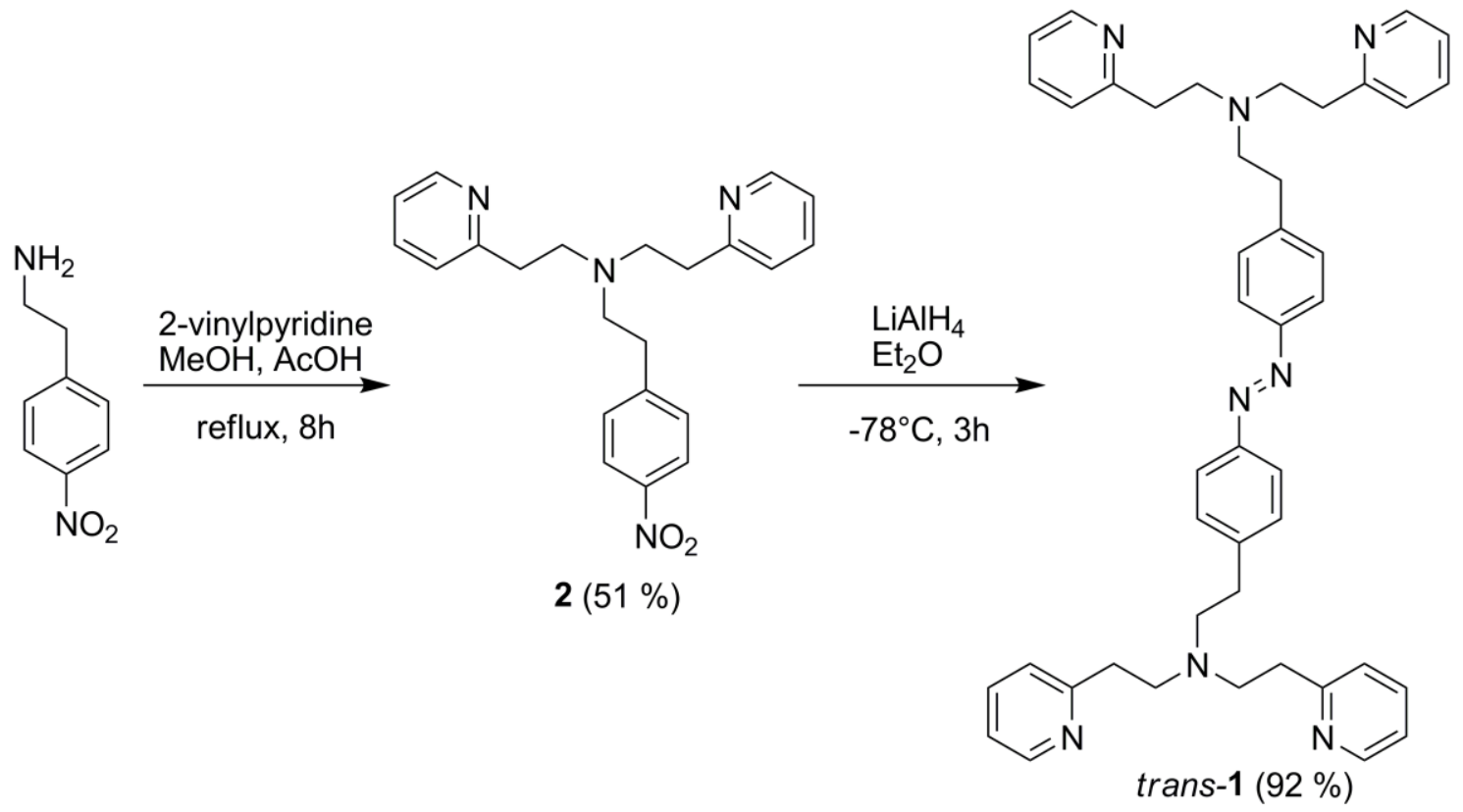

Scheme 1. Synthesis of trans-1.
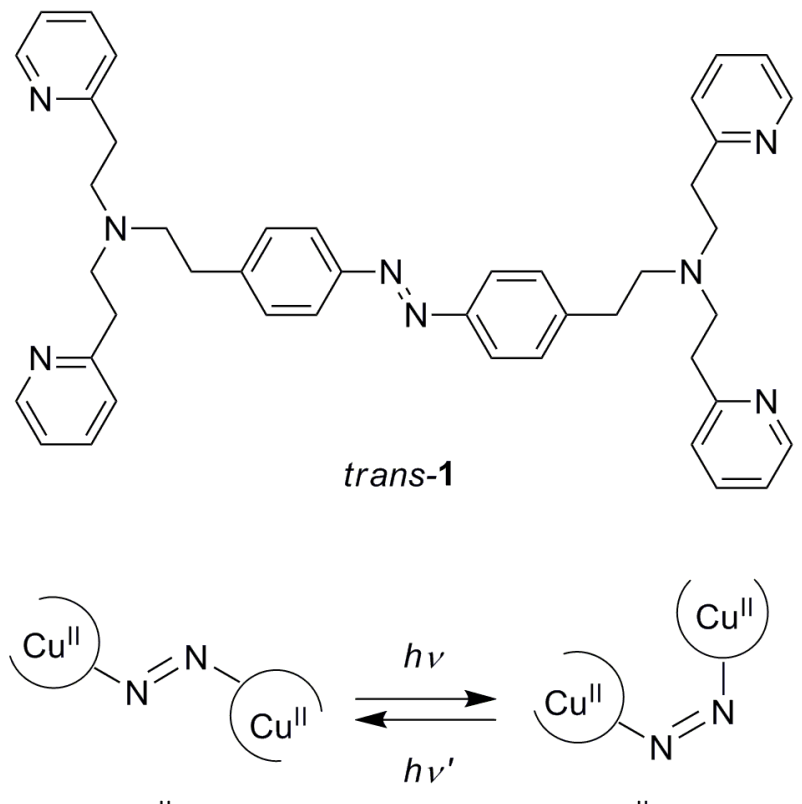

$$
\mathrm{Cu}_{2}{ }_{2} \text { trans-1 } \quad \mathrm{Cu}_{2}{ }_{2} \text { cis-1 }
$$

Fig. 1. Photoinduced tran-cis isomerization of $\mathrm{Cu}_{2}{ }_{2} \mathbf{1}$. 


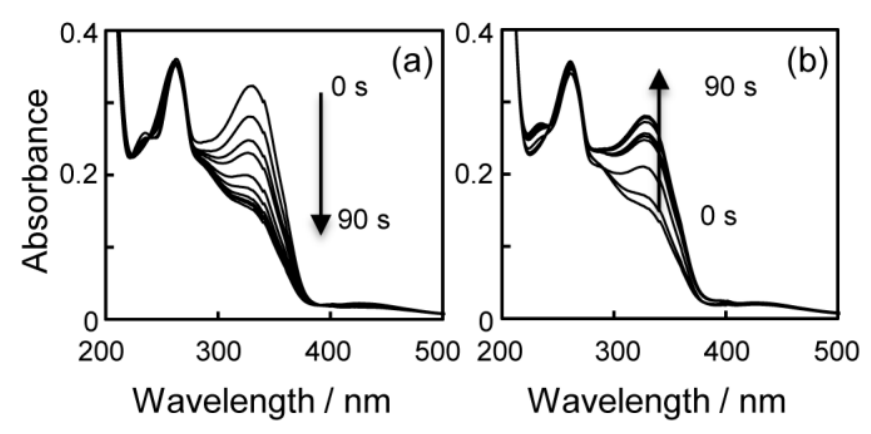

Fig. 2. Absorption spectra of $\mathrm{Cu}_{2}{ }_{2} \mathbf{1}(10 \mu \mathrm{M})$ in acetonitrile. (a) $\mathrm{Cu}_{2}{ }_{2}$ trans- $\mathbf{1}$ was exposed to 365-nm UV light for 0-90 s. (b) Further exposure of the solution to 420-nm visible light for 0-90 s. 
(A)

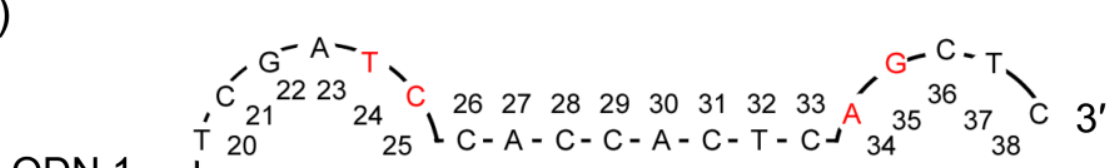

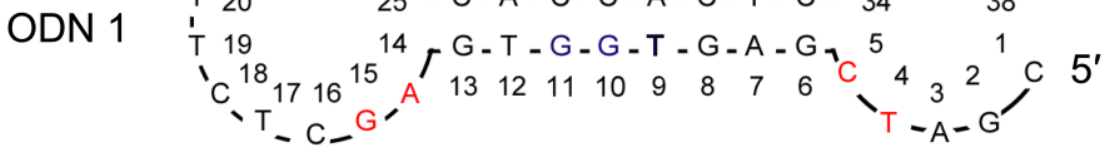

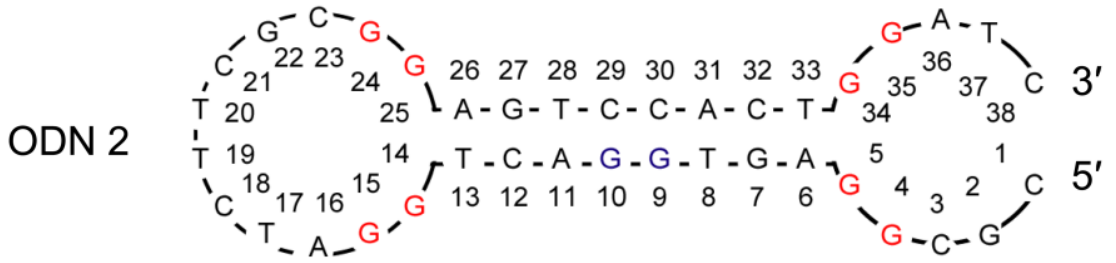

(C)

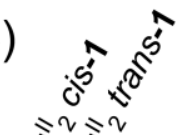
$0^{5} 0^{2}$
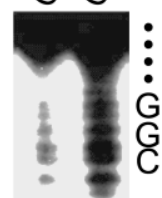

(B)

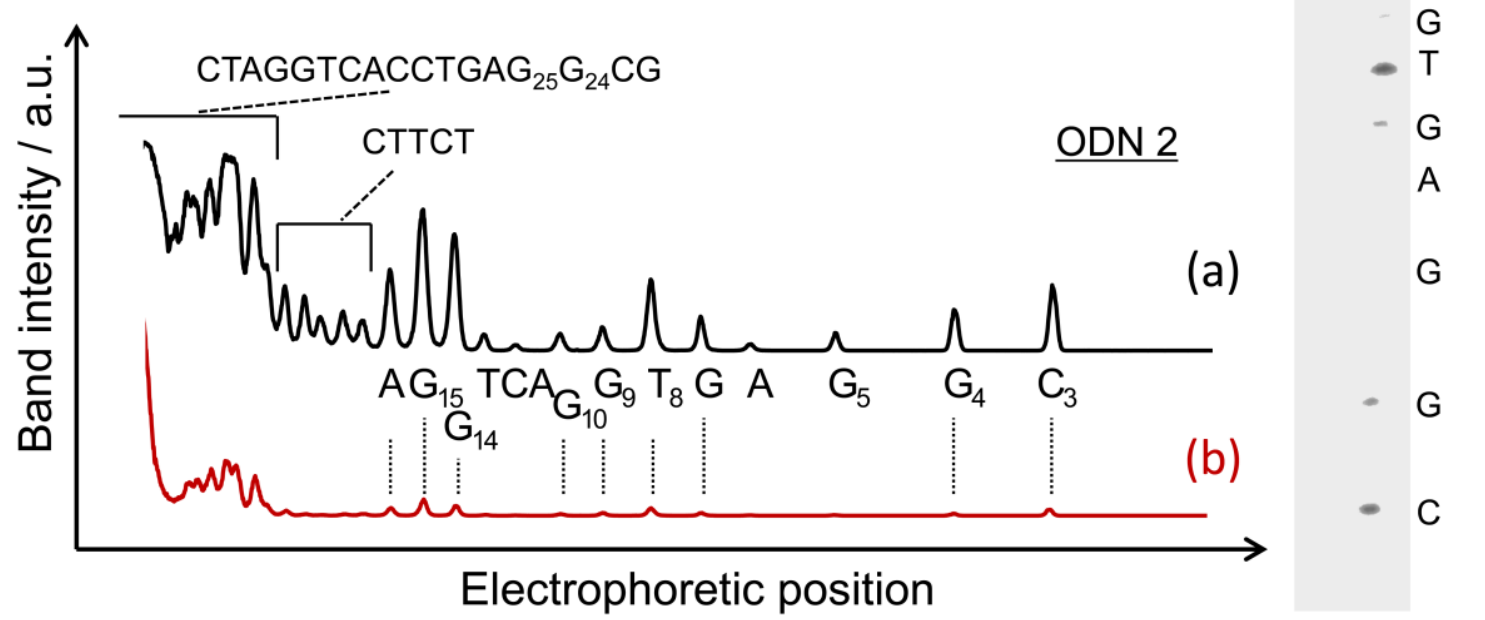

Fig. 3. (A) DNA sequences of ODN 1 and 2. GG-sites were inserted in the middle of double helices of ODNs 1 and 2 and near the single-strand-double helix junctions of ODN 2; (B,C) Polyacrylamide gel electrophoresis of the products obtained from ODN 2. A typical gel image of the products (C) and their densitometer traces (B). ODN 2 was incubated either with (a) $\mathrm{Cu}_{2}{ }_{2}^{\mathrm{II}}$ trans- $\mathbf{1}$ or (b) $\mathrm{Cu}_{2}$ II $c i s-\mathbf{1}$. 


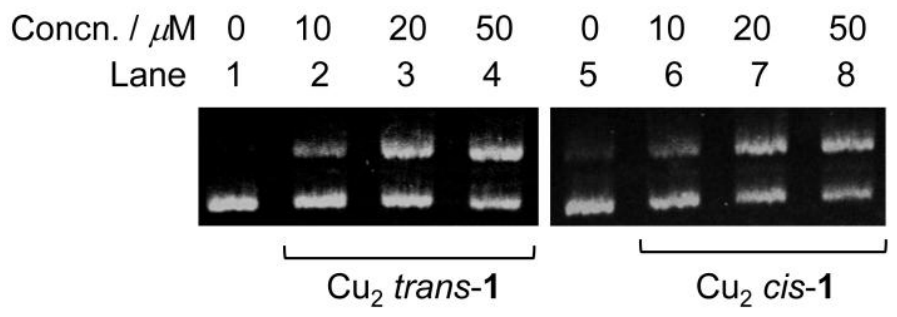

Fig.4. Agarose gel electrophoresis of DNA cleavage products. pUC19 plasmid DNA (40 $\mu \mathrm{M} / \mathrm{bp})$ in Tris-HCl-NaCl buffer $(100 \mathrm{mM}, \mathrm{pH} 7.4)$ was incubated with $\mathrm{Cu}_{2}{ }_{2}$ trans-1 or $\mathrm{Cu}_{2}{ }_{2}$ cis-1 $(0-50$ $\mu \mathrm{M})$ in the presence of MPA $(1 \mathrm{mM})$ at $37^{\circ} \mathrm{C}$ for $30 \mathrm{~min}$.
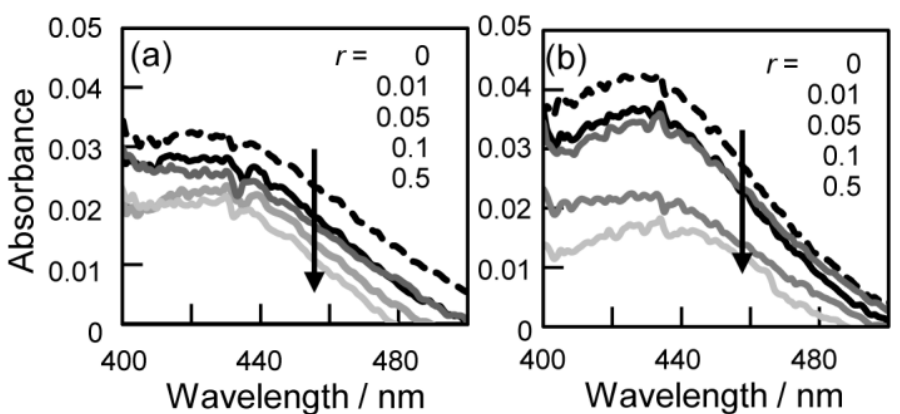

Fig. 5. Absorption spectra of (a) $\mathrm{Cu}_{2}{ }_{2}$ trans -1 and (b) $\mathrm{Cu}_{2}{ }_{2}$ cis-1 $(50 \mu \mathrm{M})$ in Tris-HCl-NaCl buffer ( $5 \mathrm{mM}, \mathrm{pH}$ 7.4) with increasing concentration of poly dG/poly $\mathrm{dC} ; r=$ [poly $\mathrm{dG} /$ poly $\mathrm{dC}] /[$ copper complex $]=0-0.5$. 


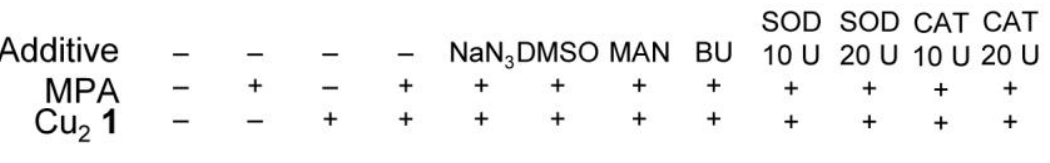

(a) Lane $\begin{array}{lllllllllllll}1 & 2 & 3 & 4 & 5 & 6 & 7 & 8 & 9 & 10 & 11 & 12\end{array}$

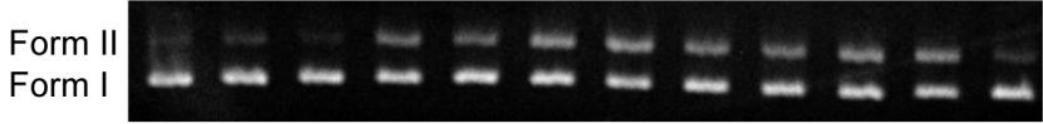

(b) Lane $\begin{array}{lllllllllllll}1 & 2 & 3 & 4 & 5 & 6 & 7 & 8 & 9 & 10 & 11 & 12\end{array}$

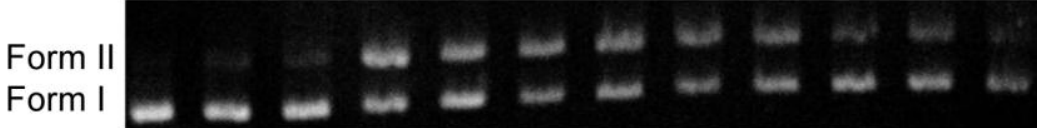

Fig. 6. Agarose gel electrophoresis of DNA cleavage products. pUC19 plasmid DNA ( $40 \mu \mathrm{M} / \mathrm{bp}$ )

in Tris- $\mathrm{HCl}-\mathrm{NaCl}$ buffer (100 mM, pH 7.4) was incubated with (a) $\mathrm{Cu}_{2}{ }_{2}$ trans- $\mathbf{1}$ or (b) $\mathrm{Cu}^{\mathrm{II}}{ }_{2}$ cis- $\mathbf{1}$ (20 $\mu \mathrm{M})$ in the presence of additives for $30 \mathrm{~min}$ at $37^{\circ} \mathrm{C}$. Lane 1. DNA alone; lane 2, DNA + MPA; lane 3, DNA + Cu complex; lane 4, DNA + MPA + Cu complex; lane 5, DNA + MPA + Cu complex + $\mathrm{NaN}_{3}$; lane 6, DNA + MPA + Cu complex + DMSO; lane 7, DNA + MPA + Cu complex + MAN; lane 8, DNA + MPA + Cu complex + BU; lane 9, DNA + MPA + Cu complex + SOD (10 U); lane 10, DNA + MPA + Cu complex + SOD (20 U); lane 11, DNA + MPA + Cu complex + CAT (10 U); lane 12, DNA + MPA + Cu complex + CAT (20 U). 